\title{
Marry the Girl Next Door (Endogamy)
}

\author{
Cynthia Dzimiri \\ Department of Educational Foundations: Great Zimbabwe University: Zimbabwe
}

\section{Introduction}

There are two universal categories of marriage partner selection restrictions referred to by anthropologists as exogamy and endogamy rules. Exogamy rules require that marriage be outside of some defined social groups while endogamy requires it be within some large group such as local communities. Exogamy tells you who should not marry and endogamy tells you who would be accepted and preferred as your life partner. Social distance is the key factor here. All cultures have norms that specify whether a person brought up in that culture should marry within or outside one's cultural group. Research shows that in societies such as the United States of America ethnic and religious groups normally put pressure on their members to remain endogamous. These rules tend to be strong especially for women. Many societies have explicit or unstated rules which define potential mates as acceptable or unacceptable. This paper will examine the strengths and weaknesses of the endogamous marriage patterns which are within different types of endogamous division. An overview of endogamy marriage will be highlighted after its brief definition.

Key words: endogamy, exogamy, patrialineal, society, unilineal

\section{Endogamy}

Barnard (1997:475) defines endogamy as a "system of marriage in which individuals can only marry those from within the same kinship group." Schaefer and Lamm (1998) emphasised that endogamy is from a Greek word 'endon' which means within. It specifies the groups within which a spouse must be found and prohibits marriage with other groups. Cultures which practise endogamy require marriage between specific social groups, classes or ethnicities. For instance a Danish endogamist would require marriage only to other Danes. Despite the fact that many people tend to marry members of their own social group, there are some groups that practise endogamy very strictly as an inherent part of their moral values, traditions or religious beliefs. Therefore endogamous marriage pattern requires that marriages be sorely or preferentially contracted within particular social groups, ranges or relationships. From the functionalist view such practises help to maintain community identity, uniqueness and status. Endogamy is often applied on a society-wide level and assists in defining group boundaries. It is sometimes applied to sub- components within a larger society often to reinforce their ability to maintain restrictive access to property, power and position (en.wikipedia.org/wiki/Endogamy). Schwimmer (1995) echoes that four types of endogamous division have been observed widely and these are village, lineage, caste and class endogamy.

\section{Types of endogamous division Village endogamy}

Physical distance has an obvious effect of the range of possible marriage partners and we can expect that people will often marry the 'girl next door' because of ease and frequency of personal contact. However, some societies reinforce this tendency to transform geographical boundaries to less permeable social ones by encouraging or requiring marriage within a village or other territorial units. It occurs when people in the same village or town marry each other. This is sometimes done by convenience since some partners may be difficult to find especially in the highly rural areas (www.wisegeek.com/what-is-endogamy.htm). For example the Yanomamo of Amazonia practise an endogamous system by forming settlements composed of paired localised lineage, which are bound to exchange women according to a specific cross cousin marriage rule. Exceptions occur only when villages have less than optimal population and must contact outside marriages to acquire allies. A less rigid but still pronounced pattern of local endogamy is evident in Turkish villages (en.wikipedia.org/wiki/Endogamy).

Village endogamy, though widespread is far from universal. The Igbo of Nigeria, for example, follow the opposite tradition of village exogamy, according to which inhabitants of the same settlement, who are usually but not necessarily patrialineally related kin, are forbidden to marry. 


\section{Lineage Endogamy}

While unilineal descent structures often entail the specification of lineages as exogamous units, there are a few marked cases of preferential marriages between fellow members of the same lineage. They are normally organised through the practice of parallel cousin marriage, usually between the children of two brothers, who are both members of their father's patrilineage. An example of such marriage pattern was given by Freeman (1958) in Schaefer (2001) who quoted the Yarunos of inland Venezwela. The Yaruno male of manageable age does not engage in the kind of dating behaviour so typical of young people in the US, rather he knows that, under the traditions of their culture, he must marry one of his mother's brother's daughter or his father's sister's daughters. The young man's choice is limited because one of his uncles selects the eligible cousin that he must marry. This type of marriage is very difficult in the societies where they take love to be important in the courtship process for example in Zimbabwe where they consider cousins to be closely related, marriage of such cousins is taken as incest.

This practice is usually associated with the heed to maintain property within the family line and avoids dissipation of assets through marriage exchanges or female inheritance. Lineage endogamy is most frequently found in pastoral communities, in which the continuity of domestic herds forms a primary concern. It is also found as a common culture pattern in Middle Eastern societies including those of contemporary Arab communities and ancient Israel.The Bible offers an extensive demonstration of lineage endogamy among the generations of the Hebrew patriarchs. Isaac, Jacob and Esau are purported to have married parallel cousins within their lineage and the text alludes to a half sibling relationship between Abraham and Sarah. It also stresses the need of parallel cousin marriage to preserve the patrilineal inheritance of property in general situations in which a man has only daughters. If they marry their father's brother's sons, their family property can be transmitted to their son's remain within the patrilineal group.

\section{Caste Endogamy}

Castes are hereditary social divisions that are distinguished from one another by property ownership, occupation, political position and often ritual status (Haralambos and Holborn,2008). Men and women are normally bound to marry within their casts of birth to maintain the purity of hereditary lines and to enclose alliances and exchanges within group boundaries. The standard model of caste is taken from traditional East Indian society, where membership in heredity groups strictly determined occupation and ritual purity. The Nayar case provides an example of such a group. They hold a high rank in their local caste system according to their ownership of agricultural land and their traditional status and occupation as political leaders and warriors. They are economically served by lower caste members and are forbidden to engage in sexual relations with them. Their marriage ceremonies are almost exclusively devoted to symbolically uniting males and females within the caste. Nayar women, particularly those on higher sub-castes, do form liaisons with even higher caste Brahmins. However the latter do not consider these affairs as marriages and do not accept responsibilities for any children that may result. They may undertake the relevant midwife payments but, unlike the Nayar, they don't consider this custom to be an actual acknowledgement of paternity. Other examples of caste endogamy include medieval Europe, where nobles were prohibited from marrying commoners, and close home, apartheid in South Africa, where interracial cohabitation was illegal.

A less exotic example of a caste society can be drawn from the history of racial discrimination in the United States. Prior to the civil nights rulings and legislation of the 1950's and 1960's many states at one time or another passed racial segregation laws that included the illegalization of interracial sexual contact or marriage. Legally sanctioned prohibitions on 'miscegenation' imposed annulments and prison sentences on interracial couples (enthro.paloma.edu/marriage/marriage_3.htm). Schaefer and Lamm (1998) observe that it was only after a couple of different races in America got married that the Supreme Court ruled that it was unconstitutional to prohibit marriage soley on the basis of race. However, this reversal has not eliminated a strong discriminatory bias in marriage choice. Wilkerson(1991) in Schaefer (2001) echoed that the survey data conducted in America showed that many whites still oppose interracial marriages. According to the General Social survey $66 \%$ of 1500 whites state that they would oppose a close relative's marriage to a black person. One of five whites believes that interracial should be illegal. By contrast blacks were found to be indifferent on the subject of intermarriage, nearly two thirds of the respondents stated that they would neither favour nor oppose a close relative's marriage to someone from another race. In general the social barrier evident is, like the defunct marriage laws, predominantly maintained by discriminatory attitudes and practices within the white community. Time series studies have shown that the incidence of interracial marriage is increasing, but quite slowly.

\section{Class Endogamy}

Class, like caste, involves a satisfaction of the society according to wealth, and related criteria. It differs in so far as its divisions are less rigid and allow for mobility. Status is, therefore, not strictly inherited and 
marriages between members of different strata are permissible. However, there are usually much less frequent than those between members with similar economic backgrounds and are often met with criticism and sanction. A pattern of class endogamy sometimes designated as homogony results. This observation is supported by studies of marriage pattern in American society, while reflect strong, although unacknowledged, preferences for restricting conjugal relationships on the basis of class and related divisions of ethnicity, race and religion. They also reveal an interesting dynamic of change over time (www.wisegeek.com/what-is-endogamy.htm). Furthermore, Americans tend to think of their society as deeply respectful of individual preferences and choices and apply this belief especially to people's rights to choose their partners. However statistical studies have indicated that many social forces narrowly contain marriages within the basic strata that mark American society. To some extent, this pattern follows personal considerations of compatible identities, interests, and experiences that husband and wife may share. However, it is also subject to social pressures of family, peers and the wider society, which often looks askance at unions of couples from desperate backgrounds. It may even impose penalties, extending to the point of ostracism. (Shut cut from society).

Although American society is easily categorised as a class society, the actual patterns of satisfaction are difficult to categorise, especially since they are complexly interrelated to ethnic, racial and religious considerations. Many studies have shown that Americans tend to marry within general social class boundaries. The pattern is particularly apparent if educational background as a major component of class definition is considered. An analysis of marriage patterns current in 1988 (Blackwell (1998) in Schwummer (1995) revealed a strong tendency for people to seek partners with similar educational attainments, especially at the extreme ends of the hierarchy. This is a common practice in almost all societies regardless of development. Men with six years of schooling or less were more than ten times as likely to marry wives with an equivalent educational attainment as were men with higher educational levels (39\% as opposed to $3 \%$ of the stratum). Only about $20 \%$ of this group married women who had finished high school, and less than 1\% married college graduates. At the other end of scale, approximately half the men who had received a university degree were married to other graduates and an additional $30 \%$ had wives who had received some postsecondary training. Less than $2 \%$ were partnered with women who had less than 12 years of formal education, a proportion exactly equal to the national rate of interracial marriages. Thus education stands as a major social division that determines and patterns conjugal and in-law relations. More importantly, while racial endogamy rates have generally declined, those for educational status are noticeably increasing. This trend in marriage patterns points to a broader reorganisation and polarization of North American society according to educational levels. According to Ritzer (2008) social class of parents' influence the socialization experiences and the protection children receive that is socioeconomic status of their family will have a marked influence on his or her health care, housing and educational opportunities.

Religion constitutes a second but related arena of marital choice in American society. In this case endogamy is imposed by structural rules as well as predominant prefences. Many religions, particularly catholism, Judaism, and Islam, have specific regulations that both partners must subscribe to the appropriate faith in order to contract a recognized marriage within it. Some protestant groups are more often but nevertheless stress the importance of a common religious bond for conjugal cooperation and child socialisation. In general, rates of religious endogamy differ according to the specific tradition involved as well as a number of other circumstances. A 1982 Canadian study estimated a $78 \%$ endogamy rate for Jews, $56 \%$ for Catholics and $45 \%$ for Protestants. Religious endogamy was more pronounced in the larger cities, in which it was easier to find a partner from the same background (www.answers.com/topic/exogamy-and-endogamy).

A study of American interfaith marriages among Christians in 1988 showed similar results as above as observed by Lehrer (1998) in Schwimmer (1995). The groups involved were classified into three categories Catholics, 'ecumenical' Protestants and exclusionist Protestants. In all three cases the in-marriage rate was approximately $50 \%$, although Catholics were slightly more likely to marry within their faith than either Protestant category. As in the Canadian study, locations with larger numbers of coreligionists demonstrated higher endogamy rates. More importantly, the study traced changes overtime and found that the incidence of interfaith marriages, almost doubled for Catholics and ecumenical Protestants between 1950 1958, but remained constant for exclusionist Protestant. Accordingly the main line religious groups are becoming more open and flexible on a personal if not official level. The more exclusionist Christian groups are retaining their inward looking traditions. This finding is particularly significant insofar as the fundamentalist and evangelical sects represented in this category have been showing rapid growth at the expense of the other denominations and are increasingly moulding the North American religious landscape. Interfaith marriages are also encouraged amongst most Christian groups in Zimbabwe for example the Apostle Faith followers and Seventh Day Adventists basing their belief on the biblical verse which discourage believers to be yoked with non-believers. Some strengths of the endogamous marriage patterns were highlighted in the discussion. In addition to those Gidden (2004) advocates that members of the minority groups often tend to see themselves as a people apart from the majority. They are usually physically and socially being isolated from the larger community. They tend 
to concentrate in certain neighbourhoods, cities or regions of a country .People within the minority group sometimes actively promote endogamy in order to keep alive their cultural distinctiveness. If people marry within their groups social problems become limited because their norms and values will be the same. For example the type of food they eat and even the way they prepare the food. This might be different where people of different groups marry. In an endogamous marriage there is likely to be harmony between the husband, wife and in-laws because of common cultural practices. In cases where children divert from their culture and marry from outside, children are likely to receive some punishment of being dishonoured by the parents. Haeri (2002) cited a case where a father bought a suit of fornication against his wishes. Again Haeri (2002) interviewed another lady who got married to one of her cousin brothers. The lady aired that endogamy is good practice because her family will conduct some enquiries regarding the boy's family, his job and lifestyle and habits before marriage. Therefore the lady will be knowing the kind of a man she is marrying and will not meet cultural shocks when they get married. Hurd (1980) sees endogamy as an attempt to retain the purity of the group, at the same time there will be very precise rules to avoid any possibility of incestuous marriage. Not only do interracial unions have an impact on mate selection and family formation, but they also force a society to reconsider its definitions of race and ethnicity.

Another strength of endogamous marriage was highlighted by Hurd (1980) when he says that close and frequent relationship with parents remain possible after endogamy marriage and these communities are marked in particular by tier of cooperation between the mother and her married daughter. Because they live close to each other they are able to share the chores of daily life particularly those to do with child care and child rearing. Bringing up children is not restricted to the home but is shared with kins women in the locality and sometimes it is carried out by the community as a whole. The child becomes neighbourhood centred and grows up with the constant companionship of the other children of the neighbourhood. Children thus have considerable influence upon each other's beliefs, values and activities as they grew up.

Endogamy encourages group affiliation and bonding. It is a common practice among displanted cultures attempting to make roots in new countries as it encourages group solidarity and ensure greater control over group resources. It helps minorities to survive over a long time in societies with other practices and beliefs. Furthermore (anthro.paolma.edu/marriage/marriage-3.htm) echoes that in an endogamy marriage there will be no battles in raising the children because people who have arranged marriages tend to stay married for a long time. This may be because they go into it with little or no expectations since they do not know each other that well hence there is a lot of excitement or may be it is because of the parents' support in all situations since they know each other.

\section{Limitations of endogamy marriages}

While some limitations were mentioned here and there in the discussion, Haeri (2002) echoes that, the way marriages are arranged precludes physical intimacy definitely. She went on to say in such marriages, in most cases physical intimacy is never established, even until the last day of one's life. A case study she carried out reflected that these cultural barriers to have meaningful physical relations hamper one's maturity and the development of one's personality absolutely for both men and women. Her research showed that men, who marry women they do not like, go to prostitutes because in their homes they will be leading very sad and lonely lives.

In general marriage is meant for peace and reconciliation that is appreciating other people's social life. Haralambos and Holborn (2008) echo that unless norms are shared members of society would be unable to cooperate or even comprehend the behaviour of others. The common educational curriculum has helped to instil shared norms and values into a population with diverse backgrounds. In a school the child must interact with other members of the school community in terms of a fixed set of rules. Thus Durkheim in Haralambos and Holborn (2008) believe that it is by respecting the school rules that the child learns to respect rules in general and that he develops the habit of self-control and restraints. Children from endogamous marriages may have problems with this because they are not exposed to different norms and values (rules) except those from their parents only.

Hurd (1980) notes that there is some reason to believe that sexual union between close kin may in certain circumstances have an undesirable genetic effect. He explains further that it is by no means unknown for human societies to adopt habits and to cling to them for centuries even though they are biologically harmful. He added that biological arguments are not a very satisfactory explanation of the universality of the taboo on incest and they are no explanation at all of the variations from society to society of the relatives who shall be included in the prohibition whatever the explanation of the incest taboo and the prohibitions on marriage that accompany it, its major function is to compel the young adult to participate in social groupings other than that of the parents. Therefore marriage must be between clans and they form reciprocal obligations which give everyone an interest in other clans and so enhance economic cooperation. 
Haeri (2002) echoes that on medical grounds hereditary diseases may be passed on to the children if people of the same blood group marry. It is also believed that the off springs from endogamous marriages are likely to be either very good or very weak. To avoid all these negative effects on children some societies encourage inter marriages. She also highlights that socialisation in the family is the beginning of that internalisation of the culture of the family's society which will go on throughout the individual's life, unless he suffers some partial or total alienation from that culture. The role relationships which are required in society may be totally lacking in the home, not necessary because it is a bad home but because the beliefs of the parents are restricted and restricting. Schaefer (2001) also points out those families from such marriage patterns help in maintaining inequality in societies. This is especially true in caste and class endogamy, which maintains that those from well to do families will remain wealth and the low-class ones will also remain low and this also applies to their educational opportunities. The resources affect children to pursue with their education and specialized lessons. In addition to the above limitations (www.wisegeek.com/what-is-endogamy.htm) says population genetics and inbreeding may lead to a group's extinction rather than its survival as genetic diseases may develop that can affect a large percentage of the population or concentrating deleterious genes which lead to sterility, serious birth defects and other issues such as development of disabilities.

\section{Conclusion}

Different cultures have different patterns of marrying. The paper has looked at different types of endogamous marriages among people. These types were identified as village endogamy, lineage endogamy, caste endogamy and class endogamy. The strengths and limitations of the endogamous marriage patterns were also examined in the paper. However from the above discussion there are more advantages than disadvantages in endogamous marriages. Conclusively, it is better to marry the girl next door than marrying a stranger.

\section{References}

[1]. Barnard, A and Burgess, T (1997) Sociology Explained. United Kingdom, Cambridge

[2]. Giddens, A (2004) Sociology, United Kingdom, Blackwell

[3]. Haeri,S (2002) No shame for the sun,USA, Syracuse University Press

[4]. Haralambos, M and Holborn, M. (2008) Sociology: Themes and Perspectives. London, Bell and Hyman

[5]. Hurd, G (1980) Human Societies. London, Routledge and Kegan Paul.

[6]. Schwimmer, B (1995) Endogamy University of Manitoba http//en.wikipedia org/wiki/..Endogamy accessed 30/10/13.

[7]. Schaefer, R T (2001) Sociology New York, McGraw- Hill

[8]. Schaefer, R T and Lamm, R P (1998) Sociology. United States of America, McGraw-Hill.

[9]. Ritzer, G. (2008) Sociological Theory, New York: McGraw-Hill

[10]. anthro.paloma.edu/marriage/marriage $3 . \mathrm{htm}$

[11]. en.wikipedia.org/wiki/Endogamy

[12]. www.answers.com/topic/exogamy-and-endogamy accessed 30/10/13

[13]. www.wisegeek.com/what-is-endogamy.htm accessed 30/10/13 